Dicle Tıp Dergisi / Dicle Med J (2019) 46 (2) : 335 - 343

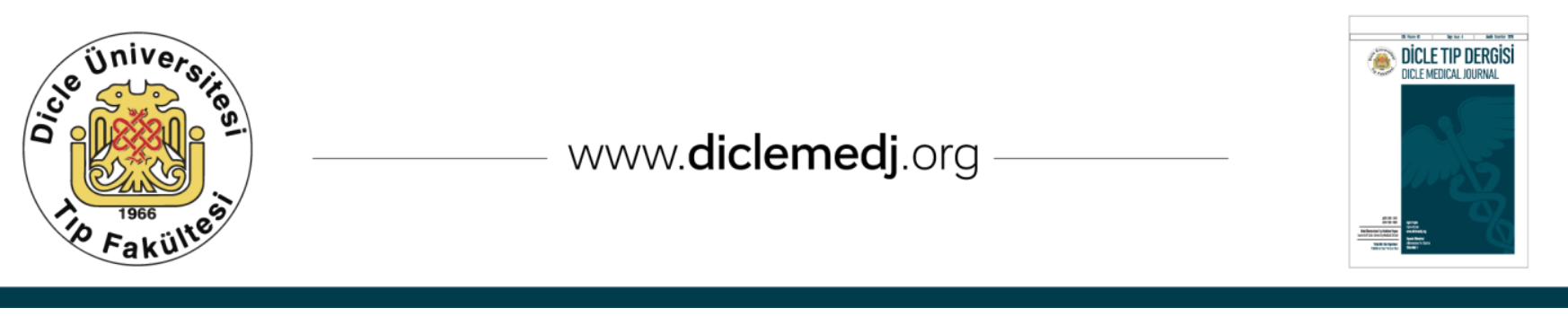

Özgün Araștırma / Original Article

\title{
Obez Çocuk ve Adölesanlarda Tiroid Fonksiyonlarının Değerlendirilmesi
}

\author{
Edip Unal $^{1}$, Funda Feryal Taş ${ }^{2}$, Mustafa Mesut Kaya ${ }^{3}$, Ruken Yıldırım ${ }^{4}$, Fesih Aktar ${ }^{5}$, \\ Yusuf Kenan Haspolat ${ }^{6}$
}

1 Diyarbakır Kadın Doğum ve Çocuk Hastalıkları Hastanesi, Çocuk Endokrinolojisi Kliniği, Diyarbakır ORCID: 0000-0002-9809-0977

2 Dicle Üniversitesi Tıp Fakültesi Çocuk Endokrinolojisi Bilim Dal, Diyarbakır ORCID: 0000-0003-2438-0602

3 Dicle Üniversitesi Tıp Fakültesi Çocuk Sağlı̆ı ve Hastalıkları Anabilim Dalı, Diyarbakır ORCID: 0000-0002-8111-0468

4 Diyarbakır Cocuk Hastalıkları Hastanesi, Cocuk Endokrinolojisi Kliniği, Diyarbakır ORCID: 0000-0002-9558-3856

5 Dicle Üniversitesi Tıp Fakültesi Çocuk Sağlı̆ı ve Hastalıkları Anabilim Dalı, Diyarbakır ORCID: 0000-0002-0760-5681

6 Dicle Üniversitesi Tıp Fakültesi Çocuk Endokrinolojisi Bilim Dalı, Diyarbakır ORCID: 0000-0003-1930-9721

Geliş: 30.01.2019; Revizyon: 30.04.2019; Kabul tarihi: 08.05.2019

$\ddot{0} \mathbf{z}$

Amaç: Bu çalışmada, obez çocuk ve adölesanlarda tiroid fonksiyonları ile metabolik ve antropometrik parametreler arasındaki ilişkinin değerlendirilmesi amaçlanmıştır.

Yöntemler: Çalışmaya pediatrik endokrinoloji polikliniğinde eksojen obezite tanısı konulan 147 hasta ile benzer yaş ve cinsiyette 46 sağlıklı birey alındı. Obez hastalar Grup 1 (karaciğerde yağlanma olmayan) ve Grup 2 (karaciğerde yağlanma olan) olarak iki gruba ayrıldı. Hasta ve kontrol grubundaki (Grup 3) tüm vakalardan açlık glukoz, insülin, total kolesterol, trigliserid, aspartat aminotransferaz, alanin aminotransferaz, tiroid uyarıcı hormon (TSH), serbest triiyodotironin (fT3) ve serbest tiroksin (fT4) için örnek alındı. İnsülin direnci HOMA-IR (Homeostatic Model Assesment for Insulin Resistance) ile değerlendirildi.

Bulgular: Grup 2'de bel çevresi (BÇ), beden kitle indeksi - standart deviasyon skorları (SDS), kalça çevresi (KÇ), BÇ/KÇ oranı ile trigliserid, açlık insülin ve HOMA-IR değerleri Grup 1 ve Grup 3'e göre anlamlı derecede yüksek iken yüksek dansiteli lipoprotein kolesterol düzeyi daha düşük idi.

Obezitesi olan gruplarda (karaciğerde yağlanma olan ve olmayan) fT4 düzeyi kontrol grubuna göre anlamlı düzeyde düşük iken fT3/fT4 oranı daha yüksek idi. Ortalama TSH düzeyi Grup 2'de Grup 3'e göre daha yüksek saptandı. fT3/fT4 oranı; BÇ, BÇ/KÇ oranı, açlık insülin ve HOMA-IR ile pozitif korelasyon göstermekteydi.

Sonuç: Obez çocuklarda fT4 düzeyinin düşük olduğu, fT3/fT4 oranının ise daha yüksek olduğu tespit edilmiștir. Obez çocuklarda yüksek fT3/fT4 oranının saptanması durumunda bu oranın BÇ ve insülin direnci ile pozitif korelasyon gösterdiği düşünülerek visseral yağ dokusuyla ilişkili komplikasyonlar konusunda klinisyen için uyarıcı olmalıdır.

Anahtar kelimeler: insülin direnci, karaciğer yağlanması, obezite, tiroid fonksiyonları.

DOI: $10.5798 /$ dicletip

Yazışma Adresi / Correspondence: Edip Unal, Diyarbakır Kadın Doğum ve Çocuk Hastalıkları Hastanesi, Çocuk Endokrinolojisi Kliniği, Diyarbakır, Türkiye.e-mail:edip76@yahoo.com 


\title{
Evaluation of Thyroid Function in Obese Children and Adolescents
}

\begin{abstract}
Background: The aim of this study was to evaluate the relationship between thyroid functions and metabolic and anthropometric parameters in obese children and adolescents.

Methods: The study included 147 patients diagnosed with exogenous obesity in the pediatric endocrinology outpatient clinic and 46 healthy subjects with similar age and sex. Obese patients were divided into two groups as Group 1 (non-fatty liver) and Group 2 (with fatty liver). Fasting glucose, insulin, total cholesterol, triglyceride, aspartate aminotransferase, alanine aminotransferase, thyroid stimulating hormone (TSH), free triiodothyronine (fT3) and free thyroxine (fT4) samples were performed from all cases in patient groups and control group (Group 3). Insulin resistance was assessed by HOMA-IR (Homeostatic Model Assessment of Insulin Resistance).

Results: In Group 2, waist circumference (WC), body mass index-standard deviation scores (SDS), hip circumference (HC), WC/ HC ratio and triglyceride, fasting insulin and HOMA-IR values were significantly higher than Group 1 and Group 3 while high density lipoprotein cholesterol level was lower. In Group 1 and Group 2, fT4 level was significantly lower than Group 3, whereas fT3 / fT4 ratio was higher. The mean TSH level was higher in Group 2 than Group 3. fT3 / fT4 ratio; WC, WC / HC ratio was positively correlated with fasting insulin and HOMA-IR.

Conclusion: We found that fT4 level was low and fT3 / fT4 ratio was higher in obese children. Considering the high fT3 / fT4 ratio in obese children, this ratio should be stimulating for the clinician regarding the complications associated with visceral adipose tissue as it is positively correlated with WC and insulin resistance.
\end{abstract}

Keywords: insulin resistance, fatty liver, obesity, thyroid functions.

\section{GíRiş}

Çocukluk çağı obezitesi önemli bir sağlık sorunudur. Dünya Sağllk Örgütü (WHO) verilerine göre 2013 yılında beş yaşın altındaki kilolu ve obez çocuk sayısının 42 milyon olduğu tahmin edilmektedir ${ }^{1}$ Obezitenin patofizyolojisinde genetik, çevresel, davranışsal, metabolik ve psikolojik faktörlerin rol aldığı düşünülmektedir²,3.

Çocukluk ve adolesan dönemde görülen obezitenin birçok hormonal ve metabolik bozukluğa yol açtığı, ancak vücut ağırlığının normale dönmesi ile bu hormonal ve metabolik bozuklukların çoğunun kaybolduğu rapor edilmiştir. Obezite insülin direnci, bozulmuş glukoz toleransı, hipertansiyon, dislipidemi ve non-alkolik karaciğer yağlanması gibi metabolik bozukluklara neden olup, kardiyovasküler hastalık ve diyabet riskinde artışa yol açmaktadır ${ }^{4}$.

Tiroid disfonksiyonu obezitede en sık görülen hormonal anormalliktir ${ }^{4}$. Tiroid hormonlarının enerji harcamaları, ısı regülasyonu ve lipid metabolizmasının düzenlenmesinde önemli etkileri mevcuttur5. Daha önce obez çocuklarda yapılan çalışmalarda artmış tiroid uyarıcı hormon (TSH) sıklığı rapor edilmiştir6,7. Ayrıca TSH yüksekliği ile birlikte normal veya hafif artmış serbest tiroksin (fT4) ve/veya serbest triiyodotironin (fT3) düzeyi olduğu da gösterilmiştir ${ }^{6,8}$. Bazı çalışmalarda kilo kaybının TSH düzeylerinin yanı sıra glukoz ve lipid metabolizmasındaki bozuklukları da normalleștirdiği bildirilmiștir9,10.

Bununla birlikte, çok sayıda çalışmaya rağmen yüksek TSH seviyelerinin, normal tiroid hormon düzeylerini korumak için kompanse edici olup olmadığı henüz net değildir. Ayrıca daha önceki çalışmalarda çelişkili sonuçlar elde edildiğinden, TSH'ın obez çocuklarda metabolik bozukluklar ile ilişkili olup olmadığı da açık değildir ${ }^{11}$.

Bu çalışmadaki amacımız obez hastalarda tiroid fonksiyonlarının değerlendirilmesi ve tiroid fonksiyonları ile metabolik ve antropometrik parametreler arasındaki ilişkiyi değerlendirmektir. 


\section{YÖNTEMLER}

Çalışmaya Dicle Üniversitesi Tıp Fakültesi Çocuk Endokrinoloji polikliniğine başvuran ve eksojen obezite tanısı alan, 10-18 yaş aralığındaki hastalar alındı. Çalışmaya aşikâr hipotiroidi, cushing sendromu, büyüme hormon eksikliği, kronik ilaç kullanımı ve nöromüsküler bozukluklar gibi nedenlerle obezite gelişen hastalar alınmadı.

Çalıșmaya alınan tüm hastaların vücut ağırlığı (VA), boy, beden kitle indeksi (BKI), VA standart deviasyon skorları (SDS), boy SDS, BKI SDS, akantozis nigrikans varlı̆̆l, bel ve kalça çevresi ölçüm değerleri kaydedildi.

Çalışmaya alınan tüm hastalardan 12 saatlik açlık sonrası venöz kan örnekleri alındı. Alınan kan örneğiyle tiroid fonksiyon testleri (TSH, fT4, fT3), aspartat aminotransferaz (AST), alanin aminotransferaz (ALT), insülin, açlık kan şekeri, total kolesterol (TK), yüksek dansiteli lipoprotein kolesterol (HDL-K), trigliserid ve düşük dansiteli lipoprotein kolesterol (LDL-K) düzeyleri ölçüldü.

Çalışmaya katılan tüm hastalardan batın ultrasonografisi (USG) ile karaciğerde yağlanma olup olmadığı bakıldı. Karaciğerde yağlanma tespit edilmeyen hastalar Grup 1, karaciğerde yağlanma tespit edilen hastalar ise Grup 2 olarak adlandırıldı.

Kontrol grubu, obezitesi olmayan ancak karın ağrısı, halsizlik, saç dökülmesi gibi bir nedenle çocuk polikliniklerimize başvuran ve yapılan tetkiklerinde tiroid fonksiyon testleri, biyokimyasal parametreleri ve batın ultrasonografi incelemesi normal olan hastalardan oluşturuldu ve Grup 3 olarak adlandırıldı.

\section{Tanımlamalar}

Beden kitle indeksi vücut ağırlığı/(boy)2 formülüne göre hesaplandı. BKİ'nin yaş ve cinsiyete göre $>95$. persentil olması obezite olarak tanımlandı. Elde edilen BKI değerleri
Türk toplumundaki çocukların normal referans değerleri ile kıyaslandı ${ }^{12}$.

Bel çevresi olguların spina iliaka anterior superior ile arkus kosta arasındaki mesafenin orta noktasından geçecek şekilde ölçüldü ve saptanan değerler Türk çocuklarının normal referans değerleri ile kıyasland ${ }^{13}$.

Kalça çevresi hastanın yan tarafında durularak ve kalçaların en geniş mesafesinin çevresi alınacak şekilde ölçüldü.

Kan basıncı oturur pozisyonunda ölçüldü. Her ölçüm en az 10 dakikalık istirahat sonrası ve aynı kişi tarafından yapıldı. Hastalar için uygun manşon kullanıldı ve her hastanın kan basıncı civalı sfingomanometre ile ölçüldü. Hipertansiyon tanımlanması için Uluslararası Diyabet Federasyonunun (IDF, International Diabetes Federation) çocuk ve gençler için tanımladığı değerler referans alındı ${ }^{14}$.

Homeostasic Model Assessment for Insulin Resistance" (HOMA-IR) değeri, açlık insülin $(\mathrm{mcU} / \mathrm{ml}) \mathrm{X}$ açlık glukoz (mg/dl) / 405 formülü ile hesaplandi.

TSH normal aralığın üzerinde (TSH: 4,2-20 $\mu \mathrm{IU} / \mathrm{mL}$ arasında) ve fT4 düzeyinin normal sınırlarda olması subklinik hipotiroidi olarak adlandırıldı.

\section{İstatistiksel Analiz}

Çalışmadan elde edilen sonuçların istatistiksel analizleri SPSS 21.0 (Statistical Package for the Social Sciences - IBM $\AA$, Chicago, IL, USA) istatistik yazılım paketi kullanılarak yapıldı. Sonuçlar ortalama \pm standart sapma (SD) olarak ifade edilirken, kategorik değişkenler yüzde ve sayı olarak ifade edilmiștir. Grupların karşılaştırılmasında Student-t testi kullanıldı. Farklı gruplar arasındaki sıklıklar bakımından fark bulunup bulunmadı̆̆ Ki-Kare testleri kullanılarak karşılaștırıldı.

İki veya daha fazla değișken arasında ilişsinin olup olmadığı varsa bu ilişkinin şiddetini ortaya koymak için korelasyon analizleri yapıldı. p < 
0.05 istatistiksel değerlendirmede anlamlı kabul edildi.

Çalışma Dicle Üniversitesi Tıp Fakültesi Etik Kurulu'ndan onay alındıktan sonra yapılmıștır (06.06.2018/202).

\section{BULGULAR}

Çalışmaya karaciğer yağlanması olmayan obez 89 hasta (40'ı kız, 49'u erkek), karaciğer yağlanması olan obez 58 hasta (21'i kız, 37'si erkek) ve sağlıklı 46 vaka (19'u kız, 27'i erkek) olmak üzere 193 çocuk ve adolesan alındı. Çalışmaya alınan gruplar arasında yaş, boy ve cinsiyet açısından anlamlı fark yoktu ( $p>0.05)$. Çalışmaya alınan vakaların demografik, antropometrik ve laboratuvar özelliklerinin karşılaştırılması Tablo 1'de verilmiştir.

Birinci ve ikinci grupta BKİ-SDS değeri üçüncü gruba göre anlamlı ölçüde yüksek idi ( $\mathrm{p}<$ 0.001). Ayrıca ikinci gruptaki BKI-SDS Birinci gruba göre daha yüksek idi ( $p=0.02)$. Bel çevresi, $\mathrm{KC}$ ve $\mathrm{BÇ/KÇ} \mathrm{oranı} \mathrm{1.} \mathrm{ve} \mathrm{2.} \mathrm{grupta}$ üçüncü gruba göre anlamlı yüksek idi ( $\mathrm{p}<$ 0.001). Ayrıca ikinci gruptaki hastalarda üçüncü gruba göre $\mathrm{BC},(\mathrm{p}<0.001), \mathrm{KÇ}(\mathrm{p}=0.01)$ ve $B C ̧ / K C ̧$ oranı $(p=0.02)$ anlamlı derecede yüksek idi. Her üç grup arasında sistolik ve diastolik kan basıncı açısından anlamlı fark bulunmadi ( $\mathrm{p}>0.05)$.

Obez olan gruplarda (karaciğer yağlanması olan ve olmayan) total kolesterol ( $\mathrm{p}=0.003, \mathrm{p}=$ 0.004 , sirasıyla) ve LDL-K düzeyleri $(\mathrm{p}=0.001$, $\mathrm{p}=0.002$, sirasıyla) kontrol grubuna göre anlamlı yüksek iken, birinci ve ikinci grup arasında anlamlı farklılık mevcut değildi ( $\mathrm{p}>$ 0.05). Birinci ve İkinci Grupta TG düzeyi ( $\mathrm{p}=$ 0.003, $\mathrm{p}<0.001$, sırasılya) üçüncü gruba göre anlamlı ölçüde yüksekti. Ayrıca ikinci gruptaki TG düzeyi birinci gruba göre daha yüksek idi ( $\mathrm{p}$ $=0.01)$. HDL-K birinci $(\mathrm{p}=0.01)$ ve ikinci grupta $(\mathrm{p}<0.001)$ üçüncü gruba göre anlamlı derecede düşük idi. Ayrıca ikinci gruptaki HDL$\mathrm{K}$ düzeyi birinci gruba göre daha düşüktü $(\mathrm{p}=$ 0.02).
Açlık kan şekerleri açısından gruplar arasında farklılık saptanmadı ( $p$ > 0.05). Üçüncü grup ile karşılaştırıldığında açlık insülin ve HOMA-IR değerlerinin birinci ve ikinci grupta anlaml oranda daha yüksek olduğu görüldü $(p<$ 0.001). Ayrıca ikinci grupta açlık insülin ve HOMA-IR birinci gruba göre de anlamlı yüksek idi $(\mathrm{p}<0.001)$.

İkinci grupta AST düzeyi hem birinci grup ( $\mathrm{p}=$ $0.01)$ hem de üçüncü gruba $(p=<0.001)$ göre anlamlı yüksek idi. Karaciğer yağlanması olmayan grup ile üçüncü grup arasında AST ölçüm değerleri açısından farklılık saptanmadı. İkinci gruptaki ALT düzeyi birinci ve üçüncü gruba göre anlamlı ölçüde yüksek saptandı $(\mathrm{p}<$ 0.001). Üçüncü grup ile klyaslandığında birinci gruptaki ALT düzeyi daha yüksek idi ( $\mathrm{p}<$ 0.001).

Tüm gruplarda ortalama fT4 düzeyi normal aralıklarda olmasına rağmen, kontrol grubundaki fT4 düzeyi birinci $(\mathrm{p}=0.01)$ ve ikinci gruba $(p=0.04)$ göre anlamlı ölçüde yüksek idi. Ancak birinci ve ikinci grup arasında fT4 düzeyi açısından istatistiksel fark saptanmadı ( $p$ > 0.05). Obez gruplar ile sağlıklı kontrol grubu fT3 düzeyi açısından kıyaslandığında anlamlı fark yoktu ( $p>0.05)$. Her üç grup TSH açısından değerlendirildiğinde; ikinci grupta üçüncü gruba göre TSH düzeyi daha yüksek saptanırken $(p=0.04)$ birinci gruba göre anlamlı fark saptanmadı ( $p>0.05$ ). Ancak karaciğer yağlanması olan obez hastaların \%19'unda, karaciğer yağlanması olmayan obez hastaların \%12,3'ünde ve kontrol grubundaki hastaların \%4,3'ünde TSH'ın normal referans aralığın üzerinde seyrettiği tespit edildi. Üçüncü gruba göre fT3/fT4 oranı hem birinci hem de ikinci grupta anlamlı ölçüde yüksekti ( $p$ $=0.01$ ). Ancak fT3/fT4 oranı obez gruplar (karaciğer yağlanması olan ve olmayan) arasında anlamlı farklılık göstermedi ( $p>0.05$ ). 
Tablo 1: Grupların demografik, antropometrik ve laboratuvar özelliklerinin karşılaştırılması.

\begin{tabular}{|c|c|c|c|c|c|c|}
\hline & $\begin{array}{l}\text { Grup } 1 \\
\text { (89 vaka) } \\
\text { (Ortalama } \pm \text { SDS) } \\
\end{array}$ & $\begin{array}{l}\text { Grup } 2 \\
\text { (58 vaka) } \\
\text { (Ortalama } \pm \text { SDS) }\end{array}$ & $\begin{array}{l}\text { Grup } 3 \\
\text { (46 vaka) } \\
\text { (Ortalama } \pm \text { SDS) } \\
\end{array}$ & $\begin{array}{l}\text { p değeri } \\
\text { (Grup } 1 \text { ve 2) }\end{array}$ & $\begin{array}{l}\text { p değeri } \\
\text { (Grup } 1 \text { ve 3) }\end{array}$ & \begin{tabular}{|l} 
p değeri \\
(Grup 2 ve 3)
\end{tabular} \\
\hline Cinsiyet (K/E) & $(40 / 49)$ & $(21 / 37)$ & $(19 / 27)$ & 0.29 & 0.68 & 0.59 \\
\hline Yaş (ay) & $156.6 \pm 25.2$ & $161.7 \pm 24.7$ & $162.7 \pm 18.0$ & 0.23 & 0.17 & 0.80 \\
\hline Boy SDS & $0.19 \pm 1.22$ & $0.27 \pm 1.26$ & $0.02 \pm 1.4$ & 0.67 & 0.49 & 0.34 \\
\hline Ağırlık (kg) & $72.5 \pm 16.1$ & $83.7 \pm 21.6$ & $51.9 \pm 11.8$ & $<0.001$ & $<0.001$ & $<0.001$ \\
\hline BKi $\left(\mathrm{kg} / \mathrm{m}^{2}\right)$ & $29.7 \pm 3.6$ & $32.4 \pm 5.4$ & $20.0 \pm 3.2$ & $<0.001$ & $<0.001$ & $<0.001$ \\
\hline BKI-SDS & $2.45 \pm 0.52$ & $2.68 \pm 0.70$ & $-0.34 \pm 1.22$ & 0.02 & $<0.001$ & $<0.001$ \\
\hline$B C ̧(\mathrm{~cm})$ & $95.3 \pm 8.87$ & $103.5 \pm 12.5$ & $71.1 \pm 9.2$ & $<0.001$ & $<0.001$ & $<0.001$ \\
\hline KÇ (cm) & $104.1 \pm 10.1$ & $110.2 \pm 12.3$ & $89.1 \pm 13.1$ & 0.01 & $<0.001$ & $<0.001$ \\
\hline BÇ/KÇ oranı & $0.91 \pm 0.05$ & $0.94 \pm 0.60$ & $0.80 \pm 0.08$ & 0.02 & $<0.001$ & $<0.001$ \\
\hline Sistolik kan basıncı (mmHg) & $117.6 \pm 13.5$ & $120.4 \pm 16.2$ & $115.9 \pm 7.2$ & 0.26 & 0.44 & 0.08 \\
\hline Diastolik kan basıncı ( $\mathrm{mmHg}$ ) & $76.8 \pm 11.3$ & $76.6 \pm 12.5$ & $75.9 \pm 5.9$ & 0.91 & 0.62 & 0.74 \\
\hline TC (mg/dl) & $165.0 \pm 31.5$ & $165.8 \pm 33.8$ & $149.1 \pm 21.2$ & 0.88 & 0.003 & 0.004 \\
\hline TG (mg/dl) & $119.1 \pm 76.9$ & $151.0 \pm 80.3$ & $83.5 \pm 28.3$ & 0.01 & 0.003 & $<0.001$ \\
\hline LDL-K (mg/dl) & $91.4 \pm 27.9$ & $92.3 \pm 30.0$ & $76.8 \pm 16.6$ & 0.84 & 0.001 & 0.002 \\
\hline HDL-K (mg/dl) & $50.3 \pm 12.2$ & $45.9 \pm 10.8$ & $55.7 \pm 12.0$ & 0.02 & 0.01 & $<0.001$ \\
\hline AKŞ (mg/dl) & $88.8 \pm 6.77$ & $90.3 \pm 7.5$ & $90.3 \pm 9.09$ & 0.22 & 0.29 & 0.99 \\
\hline Açlık insülin $(\mu \mathrm{lU} / \mathrm{mL})$ & $21.7 \pm 9.6$ & $29.3 \pm 15.1$ & $11.5 \pm 3.6$ & $<0.001$ & $<0.001$ & $<0.001$ \\
\hline HOMA-IR & $4.7 \pm 2.2$ & $6.6 \pm 3.6$ & $2.5 \pm 0.8$ & $<0.001$ & $<0.001$ & $<0.001$ \\
\hline AST (U/L) & $21.7 \pm 7.3$ & $25.4 \pm 9.6$ & $18.6 \pm 4.4$ & 0.01 & 0.08 & $<0.001$ \\
\hline $\operatorname{ALT}(\mathrm{U} / \mathrm{L})$ & $21.3 \pm 11.1$ & $32.1 \pm 18.3$ & $13.3 \pm 5.4$ & $<0.001$ & $<0.001$ & $<0.001$ \\
\hline fT3 (pmol/L) & $6.45 \pm 0.8$ & $6.59 \pm 1.1$ & $6.2 \pm 0.8$ & 0.42 & 0.24 & 0.13 \\
\hline fT4 (pmol/L) & $15.8 \pm 1.8$ & $15.9 \pm 2.1$ & $16.7 \pm 2.0$ & 0.96 & 0.01 & 0.04 \\
\hline TSH $(\mu \mathrm{IU} / \mathrm{mL})$ & $3.06 \pm 1.3$ & $3.2 \pm 1.55$ & $2.6 \pm 1.1$ & 0.52 & 0.07 & 0.04 \\
\hline fT3/fT4 oranı & $0.41 \pm 0.06$ & $0.49 \pm 0.08$ & $0.37 \pm 0.07$ & 0.45 & 0.01 & 0.01 \\
\hline
\end{tabular}

Grup 1: Karaciğer yağlanması olmayan obez hastalar, Grup 2: Karaciğer yağlanması olan obez hastalar, Grup 3: Sağlıklı kontrol vakaları, BKİ: Beden kitle indeksi, SDS: Standart deviasyon skoru, BÇ: Bel çevresi, KÇ: Kalça çevresi, TC: Total kolesterol, TG: Trigliserid, LDL-K: Düşük dansiteli lipoprotein kolesterol, HDL-K: Yüksek dansiteli lipoprotein kolesterol, HOMA-IR: Homeostasic model assessment of insulin resistance, AST: Aspartat aminotransferaz, ALT: Alanin aminotransferaz, fT3: Serbest triiyodotironin, fT4: Serbest tiroksin, TSH: Tiroid uyarıcı hormon.

TSH ile TG arasinda pozitif; fT3 ile AST, ALT, glukoz ve $\mathrm{BÇ/KÇ} \mathrm{oranı} \mathrm{ile} \mathrm{pozitif} \mathrm{(Tablo} \mathrm{2)} \mathrm{ve}$ fT3/FT4 oranı ile BÇ, BÇ/KÇ oranı, sistolik kan basıncı, açlık insülini, HOMA-IR, AST ve ALT ile pozitif korelasyon varken (Tablo 3 ), fT4 düzeyi ile BKİ, BÇ, KÇ, sistolik kan basıncı, açlık insülini ve HOMA-IR ile negatif korelasyon vardi (Tablo 4). 
Tablo 2: FT3 düzeyinin antropometrik ve metabolik parametrelerle korelasyonu.

\begin{tabular}{|l|l|l|}
\hline & \multicolumn{2}{l|}{ FT3 } \\
\hline & r & p değeri \\
\hline Yaş (ay) & -0.32 & $<0.001$ \\
\hline BÇ/KÇ oranı & 0.21 & 0.003 \\
\hline Glukoz (mg/dl) & 0.18 & 0.012 \\
\hline ALT (U/L) & 0.22 & 0.002 \\
\hline AST (U/L) & 0.31 & $<0.001$ \\
\hline
\end{tabular}

R: Korelasyon katsayısı, fT3: Serbest triiyodotironin, BÇ: Bel çevresi, KÇ: Kalça çevresi, ALT: Alanin aminotransferaz, AST: Aspartat aminotransferaz

Tablo 3: FT3/FT4 oranının antropometrik ve metabolik parametrelerle korelasyonu.

\begin{tabular}{|l|l|l|}
\hline & \multicolumn{2}{l|}{ fT3/fT4 oranı } \\
\hline & r & p değeri \\
\hline TG $(\mathrm{mg} / \mathrm{dl})$ & 0.16 & 0.021 \\
\hline BÇ/KÇ oranı & 0.23 & 0.001 \\
\hline ALT (U/L) & 0.20 & 0.005 \\
\hline AST $(\mathrm{U} / \mathrm{L})$ & 0.19 & 0.006 \\
\hline BÇ (cm) & 0.16 & 0.018 \\
\hline Sistolik KB $(\mathrm{mmHg})$ & 0.15 & 0.036 \\
\hline İnsülin $(\mu \mathrm{IU} / \mathrm{mL})$ & 0.25 & $<0.001$ \\
\hline HOMA-IR & 0.26 & $<0.001$ \\
\hline
\end{tabular}

R: Korelasyon katsayısı, fT3: Serbest triiyodotironin, fT4: Serbest tiroksin, TG: Trigliserid, BÇ: Bel çevresi, KÇ: Kalça çevresi, ALT: Alanin aminotransferaz, AST: Aspartat aminotransferaz, KB: Kan basincl, HOMA-IR: Homeostasis model assessment of insulin resistance.
Tablo 4: FT4 düzeyinin antropometrik ve metabolik parametrelerle korelasyonu.

\begin{tabular}{|c|c|c|}
\hline & \multicolumn{2}{|l|}{ FT4 } \\
\hline & $r$ & p değeri \\
\hline Yaş (ay) & -0.15 & 0.037 \\
\hline VA (kg) & -0.19 & 0.006 \\
\hline BKi $\left(\mathrm{kg} / \mathrm{m}^{2}\right)$ & -0.15 & 0.034 \\
\hline BÇ $(\mathrm{cm})$ & -0.19 & 0.008 \\
\hline $\mathbf{K C ̧}(\mathrm{cm})$ & -0.16 & 0.022 \\
\hline Sistolik KB (mmHg) & -0.14 & 0.049 \\
\hline İnsülin ( $\mu \mathrm{IU} / \mathrm{mL})$ & -0.22 & 0.002 \\
\hline HOMA-IR & -0.20 & 0.004 \\
\hline
\end{tabular}

R: Korelasyon katsayısı, fT4: Serbest tiroksin, BÇ: Bel çevresi, KÇ: Kalça çevresi, VA: vücut ağırlığı, BKİ: beden kitle indeksi, KB: Kan basıncl, HOMA-IR: Homeostasis model assessment of insulin resistance.

\section{TARTIŞMA}

Çocukluk çağı obezitesinin yaygınlığı son 30 yılda artmış olup, tüm dünyada önemli bir sağlık sorunu haline gelmiștiri15,16. Obez çocuklarda yapılan bir çok çalışmada en sık görülen hormonal anormalliğin hafif TSH yüksekliği ve ılımlı fT3 konsantrasyonundaki artış olduğu gösterilmiştir6,8,11,17-19. Total T4 ve fT4 düzeyinin genellikle açlık ve aşırı beslenme durumundan etkilenmediğ $\mathrm{i}$ bilinmektedir $6,8,19,20$. Tiroid fonksiyonlarında görülen değişikliklerin; daha fazla kilo alımını azaltmak için enerji harcamasını arttıran bir uyum süreciyle ilişkili olduğu düşünülmektedir ${ }^{4}$. Çalışmamızda ortalama TSH düzeyi; karaciğer yağlanması olan obez grupta kontrol grubuna göre anlamlı ölçüde yüksek saptanırken, karaciğer yağlanması olan grup ile yağlanması olmayan grup arasında istatistiksel olarak anlamlı bir yükseklik saptanmadı. Ülkemizde Bilgin ve arkadaşlarının yaptıkları çalışmada da çalışmamıza benzer şekilde karaciğer yağlanması olan grup ile yağlanması olmayan grup arasında TSH açısından anlamlı bir fark saptanmamıștı ${ }^{16}$. Pacifico ve arkadaşlarının çalışmalarında ise; yağlı karaciğeri olmayan obez hastalara göre yağlı 
karaciğeri olan obez hastalarda TSH konsantrasyonunun anlamlı ölçüde daha yüksek olduğu tespit edilmiştir ${ }^{21}$. Obez çocuklarda daha önce yapılan bazı çalışmalarda artmış TSH'ın BKİ-SDS ile pozitif korelasyon gösterdiği ${ }^{7,8,20,22-24}$, bazı çalışmalarda ise BKISDS ile korelasyon göstermediği ${ }^{25,26}$ rapor edilmiştir. Çalışmamızda TSH ile BKİ-SDS arasında korelasyon saptanmadı. Çalışmamızda karaciğer yağlanması olan obez hastaların \%19'unda, karaciğer yağlanması olmayan obez hastaların \%12,3'ünde ve kontrol grubundaki hastaların \%4,3'ünde subklinik hipotiroidi tespit edilmiştir. Çalışmamızda tespit edilen subklinik hipotiroidi sıklığının daha önce kilolu/obez ve kontrol gruplarını içeren çocuk ve adölesanlarda yapılan çalışmalardaki sonuçlar ile benzer bulunmuştur ${ }^{20,22-24}$.

Literatürde obez çocuk hastalarda tiroid fonksiyonları ile ilgili yapılan çalışmaların çoğunda artmış TSH ile birlikte fT3 düzeyinin $\operatorname{arttığ~} 16,8,17,19,20$, ve fT4 düzeyinin normal veya hafif arttığl rapor edilmiştir6,17,19,20,25. Çalışmamızda hem karaciğer yağlanması olan hem de olmayan obez gruplarda ortalama fT4 düzeyinin literatürdeki birçok çalışmanın aksine kontrol grubuna göre anlamlı ölçüde daha düşük olduğu tespit edilmiştir. Daha önce yapılan birçok çalışmada obez hastalarda TSH artışı olduğu ve TSH'daki artışın tiroidal deiyodinaz (tip-1) artışına yol açtığı bildirilmiştir ${ }^{27}$. Deiyodinaz artışı da fT4'ün fT3'e dönüşümünü artırır ve bu da fT4 düzeyinde azalma ve fT3 düzeyinde artışla sonuçlanmaktadır 22,27 . Çalışmamızdaki fT4 düşüklüğünün artmış deiyodinaz aktivitesine bağlı olduğunu düşünmekteyiz. Marwaha ve arkadaşları ile Bilgin ve arkadaşları tarafından yapılan çalışmalarda da çalışmamıza benzer şekilde fT4 düzeyinin kontrol grubuna göre düşük olduğu gösterilmiştirir6,22.

Obeziteye bağlı karaciğer yağlanması ile fT3/fT4 oranı arasındaki ilişkiyi değerlendiren çok az çalışma vardır. Bu konuda Bilgin ve arkadaşları tarafından yapılan çalışma literatürdeki ilk çalışmadır. $\mathrm{Bu}$ çalışmada fT3/fT4 oranının karaciğerde yağlanma olan obez hastalarda karaciğerde yağlanma olmayan obez ve sağlıklı kontrol grubuna göre istatistiksel olarak daha yüksek olduğu gösterilmiştir. $\mathrm{Bu}$ durum karaciğerde yağlanması olan obez çocuklarda fT4'ün fT3'e dönüşümünü sağlayan deiyodinaz aktivitesinin artışına bağlı olduğu ve yağ birikimini azaltmak için enerji harcamasının arttığı şeklinde yorumlanmıştır. Aynı çalışmada fT3/fT4 oranının açlık insülin ve HOMA-IR ile pozitif korelasyon gösterdiği rapor edilmiştir ${ }^{16}$. Erişkin obez kadınlarda yapılan bir çalışmada ise progressif yağ birikiminin insülin direnci ve metabolik parametrelerden bağımsız olarak TSH ve fT3 seviyesindeki artış ile ilişkili olduğu gösterilmiştir. Ayrıca fT3/fT4 oranının hem bel çevresi ile hem de BKİ-SDS ile pozitif korelasyon gösterdiği bildirilmiștir ${ }^{28}$. Çalışmamızda fT3 düzeyi açısından her üç grup arasında istatistiksel olarak anlamlı fark yoktu. Kontrol grubuna göre fT3/fT4 oranı hem karaciğer yağlanması olan hem de yağlanması olmayan obez hasta gruplarında anlamlı ölçüde daha yüksek idi. Ancak karaciğer yağlanması olan ile olmayan obez grupları arasinda fT3/ fT4 oranı açısından anlamlı fark saptanmadı. Ayrıca çalışmamızda fT3/fT4 oranı BKI-SDS ile korelasyon göstermezken, $\mathrm{BÇ,} \mathrm{BÇ/KÇ} \mathrm{oranı,}$ açlık insülin ve HOMA-IR ile pozitif korelasyon göstermiştir. Bilindiği gibi obezitenin belir $\neg$ lenmesinde en yaygın kullanılan yöntem BKİ'dir. Ancak BÇ ölçümü visseral yağ doku miktarı ile daha güçlü ilişkilidir ${ }^{29}$. Bu nedenle obez çocuklarda artmış fT3/fT4 oranının visseral yağlanma ve insülin direnci ile ilişkili olabileceğini düşünmekteyiz.

Sonuç olarak; çalışmamızda obez çocuk ve adölesanlarda düşük fT4 düzeyi ile artmış fT3/fT4 oranı tespit edilmiştir. Artmış fT3/fT4 oranının daha fazla yağ birikimini engellemek için artmış deiyodinaz aktivasyonu ile ilişkili olduğu düşünülmüştür. Bulgularımız ayrıca fT3/fT4 oranı ile BÇ ve insülin direncinin 
ciddiyeti arasında bir ilişki olduğuna işaret etmektedir. Obez çocuklarda yüksek fT3/fT4 oranının saptanması visseral yağ dokusuyla ilişkili komplikasyonlar (hipertansiyon, dislipidemi, tip 2 diyabet gibi) ve insülin direnci olasılığı konusunda klinisyen için uyarıcı olmalıdır.

Çıkar Çatışması Beyanı: Yazarlar çıkar çatışması olmadığını bildirmişlerdir.

Finansal Destek: Bu çalışma her hangi bir fon tarafından desteklenmemiştir.

Declaration of ConflictingInterests: The authors declare that they have no conflict of interest.

Financial Disclosure: No financial support was received.

\section{KAYNAKLAR}

1. WHO, Fact sheet $\mathrm{N}^{\circ} 311$, Updated January 2015. Available from: http:// www.who.int/mediacentre/factsheets/fs311/en/ Erişim tarihi: 11.12 .2018

2. Haslam D, James W. Obesity. The Lancet. 2005; 366 : 1197-209.

3. Pujanek M, Bronisz A, Małecki $P$, et all. Pathomechanisms of the develop $\neg$ ment of obesity in some endocrinopathies - an overview. Endokrynol Pol. 2013; 64: 150-5.

4. Witkowska SE, Kucharska A, Ruminska M, Pyrzak B. Thyroid dysfunction in obese and overweight children. Endokrynol Pol. 2017; 68: 54-60.

5. Rotondi M, Magri F, Chiovato L. Thyroid and obesity: not a one-way interaction. J Clin Endocrinol Metab. 2011; 96: 344-46.

6. Stichel H, l'Allemand D, Gruters A. Thyroid function and obesity in children and adolescents. Horm Res. 2000; 54: 14-19.

7. Grandone A, Santoro N, Coppola F, et all. Thyroid function derangement and childhood obesity: an Italian experience. BMC Endocr Disord. 2010; 10: 8.

8. Reinehr T, Isa A, de Sousa G, Dieffenbach R, Andler W. Thyroid hormones and their relation to weight status. Horm Res. 2008; 70: 51-57.

9. Bougle D, Morello R, Brouard J. Thyroid function and metabolic risk factors in obese youth. Changes during follow-up: a preventive mechanism?. Exp Clin Endocrinol Diabetes. 2014; 122: 548-52.

10. Santos MI, Limbert C, Marques FC, Rosario F, Lopes L. Childhood obesity, thyroid function, and insulin resistance - is there a link? A longitudinal study. J Pediatr Endocrinol Metab. 2015; 28: 557-62.

11. Reinehr T. Obesity and thyroid function. Mol Cell Endocrinol. 2010; 316: 165-71.

12. Neyzi O, Günöz H, Furman A, ve ark. Türk çocuklarında vücut ağırlığı, boy uzunluğu, baş çevresi ve vücut kitle indeksi referans değerleri. Çocuk Sağlığı ve Hastalıkları Dergisi. 2008; 51: 1-14.

13. Hatipoğlu N, Öztürk A, Mazicioğlu M, et all. Waist circumference percentiles for 7- to 17-year-old Turkish children and adolescents. Eur J Pediatr. 2008; 167: 38389.

14. The IDF consensus definition of the metabolic syndrome in children and adolescents. International Diabetes Federation October 2007. http://www.idf.org/webdata/docs/Mets_definition_chi ldren.pdf. Erişim tarihi: 13.12.2018

15. Gungor NK. Overweight and obesity in children and adolescents. Journal of Clinical Research in Pediatric Endocrinology. 2014; 6: 129-43.

16. Bilgin $H$, Pirgon O. Thyroid function in obese children with non-alcoholic fatty liver disease. Journal of Clinical Research in Pediatric Endocrinology. 2014; 6: 152-57.

17. Marras V, Casini MR, Pilia S, et all. Thyroid function in obese chil $\neg$ dren and adolescents. Horm Res Paediatr. 2010; 73: 193-97.

18. Biondi B. Thyroid and obesity: an intriguing relationship. J Clin Endo $\neg$ crinol Metab 2010; 95: 361417.

19. Reinehr T, de Sousa G, Andler W. Hyperthyrotropinemia in obese children is reversible after weight loss and is not related to lipids. J Clin Endocrinol Metab. 2006; 91: 3088-91.

20. Reinehr T, Andler W. Thyroid hormones before and after weight loss in obesity. Arch Dis Child. 2002; 87: 320-3.

21. Pacifico L, Bonci E, Ferraro F, Andreoli G, Bascetta S, Chiesa C. Hepatic steatosis and thyroid function tests in overweight and obese children. Int J Endocrinol 2013; 2013: 381014.

22. Marwaha RK, Tandon N, Garg MK, et al. Impact of body mass index on thyroid functions in Indian children. Clin Endocrinol (Oxf) 2013; 79: 424-28.

23. Ghergherehchi R, Hazhir N. Thyroid hormonal status among children with obesity. Ther Adv Endocrinol Metab 2015; 6: 51-5.

24. Aypak C, Türedi O, Yüce A, Görpelioğlu S. Thyroidstimulating hormone (TSH) level in nutritionally obese children and metabolic co-morbidity. J Pediatr Endocrinol Metab. 2013; 26: 703-18.

25. Shalitin S, Yackobovitch-Gavan M, Phillip M. Prevalence of thyroid dysfunction in obese children and adolescents before and after weight reduction and its relation to other metabolic parameters. Horm Res. 2009; 71: 155-61. 
26. Aeberli I, Jung A, Murer SB, et al. During rapid weight loss in obese children, reductions in TSH predict improvements in insulin sensitivity independent of changes in body weight or fat. J Clin Endocrinol Metab. 2010; 95: 5412-18.

27. Maia AL, Goemann IM, Meyer EL, Waijner SM. Deiodinases: the balance of thyroid hormone: type 1 iodothyronine deiodinase in human physiology and disease. Journal of Endocrinology. 2011; 209: 283-97.
28. De Pergola G, Ciampolillo A, Paolotti S, Trerotoli P, Giorgino R. Free triiodothyronine and thyroid stimulating hormone are directly associated with waist circumference, independently of insulin resistance, metabolic parameters and blood pressure in overweight and obese women. Clin Endocrinol (Oxf) 2007; 67: 265-69.

29. Klein S, Allison DB, Heymsfield SB, et al. Waist circumfer 7 ence and cardiometabolic risk: a consensus statement from Shaping America's Health: Association for Weight Manage-ment and Obesity Prevention; NAASO, The Obesity Sociาety; the American Society for Nutrition; and the American Diabetes Association. Am J Clin Nutr. 2007; 85: 1197-1202. 